Ankara Üniversitesi Türk Inkılâp Tarihi Enstitüsü Atatürk Yolu Dergisi S 33-34, Mayıs-Kasım 2004, s. 33-49

\title{
Türk Basınına Göre; Patrikhane Konusu ve Patrik Araboğlu'nun İhracı Meselesi
}

\author{
İbrahim ERDAL ${ }^{*}$
}

\begin{abstract}
$\ddot{O Z E T}$
Fener Rum Patrikhanesi, Osmanl Devleti ve Milli mücadele döneminde faaliyetleri sebebiyle tartışma konusu olmuştur. Lozan Görüşmelerinde Patrikhanenin evrenselliği ve dini konumu tartışmalara sebep olmuştur.Patrikhanenin evrenselliği bugün de tartışmalara konu olmaktadır. Bu makalede tartışma konusunun dönemin basınına nasıl yansıdı̆̆ı ele alınmıştır.
\end{abstract}

\section{According To Turkish Press; Question of Remove From Country of Patriarch Araboğlu and Patriarchate Subject}

\section{ABSTRACT}

Patriarchate of Fener "Rum" had been a question due to his activities in the period of Otoman State and Turkish national struggle era. During the Lousanne Conference, it had been caused of discussion that "ekümenik" and regional position of Patriarch. "Ekümenik" position of the Patriarch have been discussing today. In this article, it is survey of that how this subject reflected to the press in this period..

\section{GİRIŞ}

Ortodoks dünyasının küçük bir parçası olan Rumlar ve Rum kilisesi, İstanbul, Antakya, İskenderiye ve Kudüs Patriklikleri olarak ayrı ayrı teşkilatlanmıştır. Doğu (Roma) İmparatorluğu'nun başkentinde olma avantajıyla İstanbul Patrikliği birinci plana çıkmış, Osmanlı Devleti döneminde imtiyaz sağlayan fermanlarla Ortodoksların sivil ve dinî başkanı

*Ankara Üniversitesi Sosyal Bilimler Enstitüsü Araştırma Görevlisi. 
durumuna gelmiştir.' Roma düşüncesi, devlet geleneği, Anadolu'nun siyasî irade ve düşüncelerine etki etmiş, bu düşünce ve Hıristiyan Ortodoks Kilisesi sayesinde Latin ve Grek olmayan Anadolu toplumları Grekleşmiş ortak bir isim olarak "Rum" ismini almış, ancak "Rum" ve "Yunan" birbirinden farklı anlam taşımıştır. ${ }^{2}$

İstanbul'un fethi ile beraber Fatih Sultan Mehmet tarafından iltifat gören Patrikler, her zaman dini statüleri gereği saygıyla karşılanmışlardır. Osmanlı Devleti'nin hakimiyeti sürecinde Patrikhane ve Patriklere Ortodoks teb_anın dinî ihtiyaçlarının giderilmesi için geniş yetkiler verilmiştir. Patrikhane ve Ortodoks dünya için bir sembol olan Patrik V. Gregorius'un asılması olayı, devlet ve Patrikhane ilişkileri açısından bir dönüm noktası olmuştur. Patrik V. Gregorius, 1821 Yunan isyanında ilgisinin bulunması üzerine asılmış, üç gün darağacında bekletilen cesedinin üzerine Patrik olarak yapması gereken işler ile suçu yazılmıştır. Daha sonra denize atılan cesedi Rumlar tarafından bulunmuş, önce Odesa'ya götürülmüş, sonra 1871 yılında Yunan meclisinin kararıyla Atina'ya getirilmiştir. $O$ gün itibariyle Fener Patrikhânesi'nin (Petro kapısı) Ortakapısı kapatılmıștır. ${ }^{3}$ Bu olaydan sonra Patrikhâne'nin Türkler aleyhine faaliyetleri daha da artmış, kurulan dernekler ile de genişlemiştir.

Fener Rum Patrikhânesi'nin resmî gazetesi olan Eklisiyastiki Alitia'da yayınlanan bir yazı Rum Patrikhânesi'nin tarihten beri süre gelen faaliyetlerinin amacını; “...Bir milletin eşitlik vaatleriyle kandırıldı $\breve{\imath} \iota$ zamanlar geçmiştir... Bu devlet ylkılıyor. Bu köhne ve çürümüş vaatlerle devlet toplanamayacaktır. Coğrafî istatistikler gösterilmesi de Türk unsurunun çoğunluğa sahip olduğuna ve dolayısıyla Rum milletinin de böyle geçersiz açıklamalarla idare-i maslahât edilmesi gerektiğine kimseyi ikna edemezsiniz. Haritaları hazırlayanlar unutmamalıdır ki Rum unsuru birçok yerlerde azınlıkta ise baba mirası üzerindeki tarihî ve sosyal haklarını kaybedemez..." . sözleriyle ortaya koymaktadır. Burada Patrikhâne, Anadolu'nun ve İstanbul'un mirasçısı olduğunu beyan ile Roma'nın mirasçısı olduklarını iddia ederken Yunanlıları da kendilerinin mirasçısı kabul etmişledir. Bu mirasçılığa dayanarak Fener Patrikhânesi Yunan ordusunun Anadolu'ya girmesiyle birlikte ayrılıkçı faaliyetlerini arttırmıştır. Patrikhane, askere yaptığı yardımların yanında asılsız şikayetlerle şehirlerin işgalini sağlamayı amaçlamış, ayrıca heyetler oluşturarak Yunan Başbakanı Venizelos'un faaliyetlerine destek vermek için Fransa ve İngiltere'ye nota

${ }^{1}$ Adnan Sofuoğlu, Fener Patrikhânesi ve Siyasî Faaliyetleri, İstanbul 1996, TTK yayını, s.12; Mustafa Ekincikli, Türk Ortodoksları, Ankara 1998, s.112.

${ }^{2}$ G. Ostrogorsky, Bizans Devleti Tarihi, çev: F. Işıltan, Ankara 1981, TTK yayını, s. 25, 411-413; Yavuz Ercan, "Türk-Yunan İlișkilerinde Rum Patrikhânesinin Rolü”, Üçüncü Askeri Tarih Semineri Bildirileri, Tarih Boyunca Türk Yunan İlişkileri, Ankara 1986, s.197, 199,201.

${ }^{3}$ Cevdet Paşa, Tarihi Cevdet, XI, İstanbul 1983, Akçă̆ Yay., s.163.

${ }^{4}$ Ercan, a.g.m., s.204. 
vermiş, yoğun çabalarıyla birçok Rum, İzmir'e giderek Yunan ordusuna asker olarak yazılmıştır. ${ }^{5}$ Fener Patrikhânesi Rum halkı üzerinde propaganda faaliyetlerinde bulunduğu gibi bunların yanında sık sık Rumlara yapıldığını iddia ettiği sözde zulümleri anlatan kitapçıklar yayınlamıştır. Patrikhâne, bu gibi haberler ile hükûmet üzerinde baskı kurabileceğini bildiğinden bu gibi iddiaları sık sık gündeme getirmiş, memleket genelindeki her olumsuz olayı Rumlar üzerine yapılmış gibi yansıtan "Kara Kitap" gibi yayınlarda bulunmuştur. ${ }^{6}$ Avrupa devletleri de bu tür yayınları fırsat bilerek iddiaların doğruluğunu araştırma gereği duymadan Osmanlı Hükûmeti üzerinde baskı oluşturmuşlardır.

\section{FENER RUM PATRIKHANESI'NINN FAALIYETLERI}

Fener Rum Patrikhânesi'nin ve Yunanistan'ın desteğinde İstanbul'da toplumun bütün kısımlarını etkileyen ve Rumlar tarafından kurulan cemiyetler yine Patrikhâne'nin yönlendirmeleri ve maddî desteğiyle çalışmışlardır. Patrikhane kontrolünde faaliyet gösteren bu derneklerden ilki Rum Muhacirîn Cemiyeti'dir. Bu cemiyet; Amerika'ya, Yunanistan'a ve Adalara göç etmiş olan Rumların tekrar İstanbul'a dönmesini sağlamak olmuş, Patrikhâne'nin Rum nüfus ile ilgili faaliyetleri konusunda çalışmış, Etniki Eterya 'nın diğer bir adıyla Kordos Komitesi'nin bir kolu olarak kullanılmıştır. Cemiyet, göçmen cemiyeti olarak görüldüğünden silahlı Rum çetelerini istediği yere nakledebilmiş, bu cemiyetin seyahat belgesini alan çete üyeleri Karadeniz'e kadar rahatça gidebilmiştir. Bunun yanında Patrikhâne ve Metropolitler aracılığıyla çetelere katılmak üzere gelen 18-20 yaş arası gençleri jimnastik ve izcilik faaliyetleri adı altında askeri eğitime tâbi tutmuştur.?

Rum Cemiyet-i Ticâriyesi de, İslâm tüccarlarının iflasa sürükleyerek piyasayı ele geçirmek, borsa oyunlarını kontrol etmek için Yunan Konsolosu'nun isteğiyle kurulmuştur. Asya-yı Suğra Cemiyeti ise Venizelos'un direktifleriyle kurulmuş ve Anadolu'nun Yunanlı olduğunu ispat için çalışmıştır. Rum Cemiyet-i Edebiyesi ise sinemalar ve tiyatrolar vasıtasıyla Yunanlılık propagandası yapmıştır. Fener Rum Patrikhânesi bu faaliyetleri sırasında Ermenilerle de işbirliği yapmıştır. Venizelos'un teşvikleri ve yönlendirmeleriyle hareket eden Rum örgütleri 6 Aralık 1918 tarihinde Zevan Efendi'nin İstanbul'a gelmesiyle faaliyetlerini arttırmışlardır. Ermeni Patrikhânesi'nin faaliyetlerine yardım edenlerin başında Rum basını ve Fener Rum Patrikhânesi gelmektedir. Rum basını propaganda esnasında Rum göçünden bahsederken her zaman Ermenilerin öldürülmesi ve toplu sürgününden bahsetmiş, 4 Ocak 1919 tarihinde Büyükada'da yapılan toplantıyla dayanışma daha da güçlenmiştir. İstanbul'a

\footnotetext{
${ }^{5}$ Tanin, 23 Temmuz 1923.

${ }^{6}$ Bülent Atalay, Fener Rum Patrikhanesinin Siyasi Faaliyetleri (1908-1923), İstanbul 2001, Tarih ve Tabiat Vakfı yayını:4, s.44

${ }^{7}$ Tanin 31 Aralık 1922.
} 
giren işgal ordularını Ermeniler ve Rumlar coşkuyla karşılamış, Ermeni ve Rum Patrikleri 1919 yılında İstanbul'a gelen General Harbourd'u birlikte ziyaret etmiş̧lerdir. ${ }^{8}$ Mustafa Kemal Atatürk Nutkunda “ ...memleketin her tarafında anasır-ı Hıristiyaniye gizli, açık, hususi emel ve maksatlarının temini istihsaline, devletin bir an evvel çökmesine sarf-ı mesai ediyorlar. Ermeni Patriği Zevan Efendi ve Mavri Mira Heyeti hem fikir çalışıyor." diyerek belirtmiş, ancak bu beraberlik Lozan Konferansı görüşmelerinde Pontus olarak kabul edilen bazı yerlerin Ermenistan tarafından kendi sınırları içinde olduğunu iddia etmesiyle son bulmuştur.

Patrikhânenin en önemli faaliyet sahasından birisi de Pontus meselesi olmuştur. Yunanistan'ın bağımsızlığına kavuşması ve Filik-i Eterya örgütünün kurulmasıyla, Pontus'un bağımsızlı̆̆ı "Megali Idea"nın hedeflerinden birisi olmuştur ${ }^{10}$. Merzifon Amerikan Kolejindeki Rum öğrenciler Megali İdea amacıyla 1908 yılında "Müdafaa-i Meşrua" adında bir ihtilâl cemiyeti kurmuşlar, 1910 yılında da "Pontus" adında bir makale yayımlamışlardır. ${ }^{11}$ Pontus Cemiyeti'nin de Merzifon Amerikan Kolejinde kurulduğu, 16 Şubat 1921 tarihinde yapılan bir aramada bulunan belgelerden anlaşılmıştır. ${ }^{12}$ Patrikhâne'nin desteğiyle kurulan bölücü cemiyetlere, Pontus cemiyetleri de katılmıştır. Türkiye'de ilk Pontus "İctimagâhı" İnebolu'da Manastır olarak adlandırılan yerde Amerika Rum göçmenlerinden rahip Klematyos tarafından kurulmuştur. ${ }^{13}$ Pontus Cemiyeti; Trabzon, Ordu, Giresun, Samsun sahil Vilayetleri ile, Kastamonu, Gümüşhâne, Sivas ve Erzincan Vilayetlerinin bir kısmını içine alan yerleri, başkent Samsun olmak üzere Yunanistan'la birleştirmek üzere bağımsız bir Pontus cumhuriyetini kurmayı ve Birinci Dünya Savaşı'nın başladığı dönemlerde Bafra civarında ilk çetecilik faaliyetlerini başlatarak; Türk ordusunu meşgul edip düşmana geri hizmet vazifesi görmeyi, pusu kurmak ve bölgede Rum nüfusunu arttırarak Rum varlığını ve çoğunluk oluşturduğunu ispat etmeyi amaçlamışlardır.

Karadeniz'deki Pontus faaliyetlerinin en önemli lideri Trabzon Metropoliti Hrisanthos olmuştur. Metropolitin kardeşleri Antaş ve Yorgi, Yunan ordusunda ve Pontus milis çeteleri içinde görev almış, Selanik ve Kafkaslarda Pontus çeteleri içinde komutanlık yapmışlardır. ${ }^{14}$ Bunlardan başka Patrikhâneye bağlı olan Havza papazı, Giresun Metropoliti Lavrentios ve Giresun belediye başkanının oğlu Konstantinidis Pontusçu faaliyetlerine Fener Patrikhânesinden aldıkları maddî manevî desteklerle devam

\footnotetext{
${ }^{8}$ Pontus Meselesi, Yılmaz Kurt (yayına hazırlayan ), Ankara 1995, s.41-49.

${ }^{9}$ Mustafa Kemal Atatürk, Nutuk, C.I, İstanbul 1950.,s.2.

${ }^{10}$ Tanin 23 Temmuz 1923.

"Pontus Meselesi, s.64.

${ }^{12}$ Hâkimiyet-i Milliye 25 Mart 1921.

${ }^{13}$ Selahattin Salışık, Tarih Boyunca Türk-Yunan İlişkileri ve Etnik-i Eterya.

${ }^{14}$ Hâkimiyet-i Milliye, 17 Mart 1922.
} İstanbul, 1968,s.44. 
etmişlerdir. ${ }^{15}$ Bu faaliyetler Birinci Dünya Savaşı başlarına kadar gizli gizli devam etmiş, savaşmamak için cepheden kaçan Rumlar, Rusların silah yardımıyla tekrar silahlandırılarak Pontusculuk faaliyetlerine dahil edilmişlerdir. ${ }^{16}$ Trabzon Metropoliti Hrisanthos, Rum çetelerinin daha düzenli hâle getirebilmek için "Rum İttihad-1 Milli Cemiyeti"ni kurdurmuş, Karadeniz vilayetlerinde şubeler açan bu cemiyet üyeleri Metropolite sadakatlerini bildirmişlerdir. ${ }^{17}$ Samsun Metropoliti Yermanos hem Müslümanlara hem de Rumlara karşı yapılan propagandadan ve yerel kuvvetlerden sorumlu iken, Trabzon Metropoliti Hrisanthos ise Fener Patrikhânesi'nin emir ve desteğiyle uluslararası görüşmelerde propaganda faaliyetinden sorumlu olmuştur. ${ }^{18}$

Patrikhâne'nin desteğiyle faaliyetlerini arttıran Rum çetelerine karşı halk milis kuvvetler oluşturarak karşı koymaya başlamıştır. Türkleri Rum çetelerinin baskısından korumak ve çetelerle daha düzenli mücadele yapabilmek için 12 şubat 1919 tarihinde Trabzon Muhafaza-i Hukuk Cemiyeti Barutçuzade Ahmet Faik tarafından kurulmuştur. ${ }^{19}$ Ortodoks Rumların faaliyetleri karşısında yine Ortodoks tebaa olan, örf ve adet itibariyle Müslüman Türklere daha yakın bir hayat süren Hıristiyan Türkler ise Kuvay-1 Milliye lehinde çalışmışlardır. ${ }^{20}$ Papaz Eftim'in önderliğindeki Ortodoks Türkler Hükûmete çektikleri telgraflar ve görüşmelerde "Türkçe'den başka bir dil bilmediklerini ve Türk olduklarını" ifade etmişler, bir Türk Ortodoks Patrikhânesi'nin kurulmasının gereğine işaret etmişler, bu talebe de hem Adliye Vekili Reşit Şevket Bey, hem de Hükûmet temsilcisi Bekir Sami Bey olumlu bakmıştır. ${ }^{21}$ Fener Rum Patrikhânesi Ortodoks Türklerin bu karşı faaliyeti üzerine olağanüstü toplanarak bu durumu kabul etmediğini bildirmiş, ${ }^{22}$ ancak Adliye Vekaleti Türk Ortodoks Patrikhânesi'nin kurulması hakkındaki kanun teklifini TBMM'ye sunmuştur. ${ }^{23}$

Ortodoks Türkler, Fener Rum Patrikhânesinin zararlı faaliyetleri karşısında 1922 yılında bağımsız Türk Ortodoks Patrikhânesini kurarak, Fener Rum Patrikhânesinin nüfuzunu kırmaya çalışmışlardır. Milli mücadele lehinde çalışan Anadolu'nun Ortodoks Türkleri, bütün vekalet ve yetkileri Papa Eftim'e verdiklerini ve onu desteklediklerini bildirmişlerdir. ${ }^{24}$ Papa

\footnotetext{
${ }^{15}$ Hâkimiyet-i Milliye, 17 Mart 1922

${ }^{16}$ TBMMGZC, İşbankası Yayını, Ankara 1985, C:.3, s.386-398.

${ }^{17}$ Hâkimiyet-i Milliye, 17 Mart 1922

${ }^{18}$ Hâkimiyet-i Milliye, 13 Mart 1922

${ }^{19}$ İzzet Öztoprak, "Trabzon Muhafaza-i Hukuk Cemiyeti”, Birinci Tarih Boyunca

Karadeniz Kongresi Bildirileri (13-17 Ekim 1986), Samsun 1988, s.335-350.

${ }^{20}$ Hâkimiyet-i Milliye, 16 Haziran 1921.

${ }^{21}$ Hâkimiyet-i Milliye, 10 Ocak 1921, 1 Mayıs 1921.

${ }^{22}$ Hâkimiyet-i Milliye, 15 Mayıs 1921.

${ }^{23}$ İkdam, 3 Mayıs 1921

${ }^{24}$ Hâkimiyet-i Milliye, 13 Ocak 1922
} 
Eftim'de Ankara'ya çağırdığı yabancı gazetecilere Fener Patrikhânesi'nin yaptığı asılsız propagandaların iç yüzünü anlatmış, Anadolu'da yaşanan hadiselerden Hıristiyanların da zarar gördüğünü buna sebep olanın da Fener Patrikhânesi olduğunu ifade etmiştir. Milli Mücadeleye katkılarına rağmen Lozan görüşmelerinde Ortodoks Türkler, diğer Rum tebaa ile birlikte mübadeleye tâbi tutulmuştur. Ortodoks Türklerin başvuruları sonucu 3 ağustos 1924 tarihli kararla sadece Papa Eftim ve ailesi mübadele harici tutulmuştur. ${ }^{25}$

\section{LOZAN KONFERANSINDA PATRIKKHÂNE MESELESİ}

Lozan'da, yapılan zararlı faaliyetlerinden dolayı Türk tarafının teklifi ile tartışma yaratan Patrikliğin İstanbul dışına çıkarılması konusu, Lord Curzon ve temsilciler tarafından tepkiyle karşılanmıştır. Ancak görüşmeler sırasında menfaat dengelerine önem verilmiş, devletler kendi politikalarını dikkatle izlemiş, bu konuyu kullanmışlardır. Amerika'nın Londra, Paris ve Roma büyükelçiliklerine verilen ve sonrada Lozan'daki delegasyona teyid edilen 30 Ekim 1922 tarihli tâlimatta, Türkiye'deki azınlıkların korunmasına büyük önem verildiği belirtilmesine rağmen, İstanbul'daki Fener Rum Patrikhânesi'nden hiç söz edilmemiştir. Lozan'a giden Türk heyetine verilen temel meseleler ile ilgili görüşleri içeren 14 maddelik talimatnâmenin içinde bulunmayan Patrikhâne'nin Türkiye dışına çıkarılması meselesi, komisyonda Dr. Rıza Nur tarafından dile getirilmiş, İsmet Paşa (İnönü) da Patrikhâne'yi, Türkler ile Rumların kaynaşıp devlet içinde birlikte yaşamalarına engel olan bir unsur olarak görmüştür ${ }^{26}$ İsmet Paşa'nın bu görüşü doğrultusunda Türk heyeti; Fener Rum Patrikhânesi'nin zararlı faaliyetlerinden dolayı, bütün organları ve kurallarıyla beraber İstanbul'dan çıkarılmasında ısrar etmiş, İstanbul'da Rum faaliyetlerinin merkezi olan Patrikhâne'ye dokunulmayacaksa bazı Rumların gönderilmesinin bir manasının olmayacağını ifade etmiştir. ${ }^{27} 12$ Aralık 1922 tarihinde İsmet Paşa bir konuşmasında Patrikhânenin Yunanistan'ın bağımsızlığını kazanması sonra da sınırlarının genişlemesi için her türlü faaliyette bulunduğunu, buna rağmen bugün Rum vatandaşlarının huzur içinde yaşadıklarını belirtmiş, Türk basını da manşetlerinde bu Rumların dışardan kullanıldıkları için Türkiye dışına çıkarılmaları hususunda Hükûmetin kesin kararlı olduğunu yazmıştır. ${ }^{28}$ Türk heyeti de Patrikhâne konusundaki kararlılıklarını 14 Aralık görüşmelerinde de sürdürmüş, ${ }^{29} 16$ Aralık 1922 tarihli oturumda alt komisyona verilen bildiride, Osmanlı Devleti'nde azınlıklara tanınmış olan bütün imtiyazların sona erdiğini, din adamları sınıfının ve liderlerinin sadece bu işle ilgilenmeleri gerektiği, bu sebeple siyasî ve diğer haklarını kaybeden

${ }^{25}$ Başbakanlık Cumhuriyet Arşivi: 30.18.1.1./10.37.1.

${ }^{26}$ İsmet İNÖNÜ, İsmet İnönü'nün Hatıraları (1923-1938), C.II, İstanbul 1998, Cumhuriyet, s. 130.

${ }^{27}$ Tanin 17 Aralık 1922; Akşam 17 Aralık 1922.

${ }^{28}$ Tanin, 17 Aralık 1922.

${ }^{29}$ Tanin, 19 Aralık 1922. 
Patrikliğin Türkiye dışına çıkması gereği ifade edilmiştir. Fransa delegesi de Patrikliğin sadece sembolik olduğu bir öneri getirerek taraflara sunmuştur.

Fransa temsilcisinin taraflara sunduğu; "Patrikhâne çok sinırlı yetkilerle Bă̆ımsız İstanbul Kilisesi olarak ve diğer Ortodoks kiliseleriyle ilişkisi kesilmiş bir şekilde İstanbul'da kalmalıdır. Patrik, Türk Hükûmeti'nin uygun gördüğü adaylar arasından seçilerek, bütün çalışmaları denetime tâbi tutulmalıdır" şartlarını içeren teklifi her iki Hükûmet temsilcisi de uygun görmüş ise de, daha sonra azınlık hakları üzerine verilen tasarılarda Patrikhânenin ayrıcalıklarının hala korunuyor olması üzerine antlaşma sağlanamamıştır.

Lozan Konferansının 18 Aralık 1922 tarihli oturumunda Türk Temsilci Rıza Nur "...Müslüman olmayan azınlıkların din adamlarına eskiden Türkiye'nin kendi girişimi ile tanımış olduğu ayrıcalıkları olduğu gibi tutmasını şimdiki Türkiye'den istemek de, özü laik olan azınlıklar yasasina da aykırıdır... Türkiye,Halifelikle devletin ayrılığın ilan etmiş, kelimenin tam anlamında çağdaş ve laik bir devlet olmuş, bunun sonucu olarak da din ile devlet birbirinden kesin olarak ayırmıştır... Konferansta, dünya işlerinin görülmesine karışmaya ve kural dışı hakların tanınmasına ilişkin herhangi bir konu, Batı devletlerinde uygulanan azınlıklar yasasının hem özüne hem sözüne aykırı düşer. bundan başka yeni Türk Hükûmetinin kabul ettiği laiklik ilkesine de aykırl olacaktır...Museviler ve Hiristiyanlar, medenî hukuka göre, yapılacak evlenmelerini ve boşanmalarını, isterlerse, kendi din makamlarına öğretebileceklerdir; fakat bu hiçbir bakımdan devleti ilgilendiren bir konu değildir...Bu haklar yeni kurulan Balkan Devletleri ve komşularımızdaki Müslümanlar içinde uygulanması gerektiğini açık ve net bildiririz." diyerek azınlık hakları bağlamında Müslümanların haklarının karşılıklılık esasına göre korunması gerektiğini vurgulamıştır. Rıza Nur'a göre Rum Patrikhânesi dünya işleri konusundaki ayrıcalıklarını Türk devletine onaylatmak, devlet içinde devlet olmak istemektedir. Venizelos ise Patriklik meselesinin ertelenebileceğini ancak Yunan Hükûmeti'nin Müslümanlara verdiği güvencenin aynen Türkiye'deki Rumlar için geçerli olmamasının kabul edilemeyeceğini ifade etmiş, Yunanlı temsilci Kaklamanos da; "Evrensel Patriklik sorununda Türk Hükûmeti uzlaşmaz bir direniş gösterdiğine göre, Yunan Temsilci Heyeti'nin, Müslümanların doğrudan doğruya Müslümanlarca seçilmesini ve Başmüftünün İstanbul'a bağlı olmasını öngören Atina Barış Andlaşması'ndaki hükümlerin, Türklerin, Patrikliğin varlığına bile karşı çıktıkları bir sırada, yürürrlükte kalmasını kabul edemeyiz." diyerek Rumların bu durumda Yunanistan'daki Türkler kadar hakka sahip olmadığını iddia etmiştir. ${ }^{30}$

Aralık ayında Lozan'da Patrikhâne ile ilgili görüşmeler yapılırken, Anadolu'da birçok zararlı faaliyetlerde bulunan, asılsız iddialarla Avrupa'yı Rumları himayeye davet eden Patrik Meletios; Lozan'da Türk temsilcilerinin

${ }^{30}$ Meray, a.g.e, C.I, K:II, s.158-160, 221. 
Patrikhânenin yetkilerinin sınırlanması konusundaki ısrarlı tutumları üzerine varlığının ve yetkilerinin kaybolacağı endişesine kapılmıştır. ${ }^{31}$ Meletios, Türk gazetecilere verdiği demeçte; " Türkler ve Rumlar ile ilgili düne ait ne varsa unutalım, yeni bir sayfa açalım.Artık Patrikhâne sadece dinî işlerle ilgilenecektir. Geçmişte çok hata yaptık. Bundan sonra Türkler ve Hiristiyanlar arasında dostluk köprüsü olmaya hazırız. Daha önce Rumlar tarafindan yapılanlar bir cinnet hâli idi. Türkler aynı şeyi bize tekrarlamayacak kadar geniş gönüllüdür. Şu anda Türklere karşı olan hürmetimiz çok daha fazla artmıştır. Çünkü onlar verdikleri mücadele ile yaşamaya hakları olduğunu bütün dünyaya ispat ettiler." 32 sözleriyle yine Türk Hükûmeti'ne karşı propaganda yaparak, Patrikhâne yoluyla var olan haklarının kaybolmamasını ve Rumların mübadele yoluyla Türkiye'den göç ettirilmemesini amaçlamıştır.

3 Ocak 1923 tarihinde İngiliz delege de bir bildiri yayınlayarak Lord Curzon'un Patrikliğin İstanbul'dan çıkarılmasıyla ilgili hiçbir öneriyi kabul etmeyeceği ifade edilmiştir. Yunan üyelerinin de Patrikliğin her zaman Ortodoks dünyanın temsilcisi olduğunu, İstanbul'dan çıksa da bunun değişmeyeceğini bildirmiş, Türk heyeti de kararında israrcı olmuştur. ${ }^{33}$ Yunan Temsilcileri Fransız temsilcinin teklifine yakın olduğunu iddia ettiği; "dinî ve dünyevî yetkiler sadece Patrikte kalacak ve yetkileri kullanabilmesi için bir Naiblik kurulacaktır. Nâib Patrik tarafından atanacak ama çalışmaları Türk Devleti'nce denetlenebilecektir". teklifi Türk heyeti tarafından reddedilmiştir. Alt komisyonlarda çözülemeyen mesele, alt komisyon başkanı Montagna tarafından hazırlanan bir rapor ile birlikte 10 Ocak 1923 tarihinde birinci komisyona gönderilmiştir. ${ }^{34}$

Patrikhâne'nin çıkarılması konusu, 10 Ocak 1923 tarihinde toplanan Arazi ve Askerlik komisyonunda tekrar görüşülmeye başlanmıştır. Lord Curzon başta olmak üzere Yugoslav, İtalyan, Fransız ve Yunan delegeler Patrikhâne'nin İstanbul'da kalmasını savunmuş, Patriğin siyasî davranmasını engelleyecek önlemlerin alınması durumunda İstanbul'da kalması çerçevesindeki İngiltere'nin teklifi desteklenmiştir. Aynı fikirde olan Venizelos'a göre ise; Türklere zarar veren Patrikhâne değil, bazı Patriklerin yanlış uygulamalarıdır. Bundan dolayı ferdî hataları kuruma yüklemek haksızlıktır. Sadece dinî vazifelerini yerine getirmesi şartıyla Patrikhâne'nin İstanbul'da kalması Türkiye'nin de işine gelecektir. ${ }^{35^{3}}$ Bunun üzerine İsmet Paşa (İnönü) yapılan bu konuşmalar ve teklif üzerine verilen bu sözleri kabul ederek Patrikliğin İstanbul'da kalmasını kabul etmiştir. ${ }^{36}$

\footnotetext{
${ }^{31}$ Tanin, 19 Aralık 1922.

${ }^{32}$ Tanin, 2 Aralık 1922.

${ }^{33}$ Akşam 17 Nisan 1923

${ }^{34}$ Meray, a.g.e., C.I, K:I, s. 333-341.

${ }^{35}$ Tanin, 9 Ocak 1923.

${ }^{36}$ Tanin, 17 Ocak 1922; Bilal N. Şimşir, Lozan Telgrafları 1922-1923, C:I, TTK yayını, Ankara 1990, s.362-363.
} 
Venizelos, Türkiye Cumhuriyeti'nde laiklik ilkesiyle beraber din ile devlet işlerinin birbirinden ayrılması, Osmanlıda var olan ruhan̂̀ ve siyasî liderliğin ayrılmasını da sağlamıştır. Bu sebeple din adamlarının sırf din̂े işerle uğraşması daha iyi olacaktır, açıklamasını yapmıştır. Lozan Konferansında Patrikhâne konusu görüşüldüğü sırada Büyük Millet Meclisinde de tartışmalar devam etmiştir. İcra Vekilleri Heyeti Başkanı Rauf Bey verdiği bir demeçte "Fatih hazretlerinin bir lütûf ve âtıfet olarak ihsan ettiği müsaadata, ahfadı bizler, kemal-i hürmetle riayet ettiğimiz hâlde, mukâbilinde hiyânet, hayatımıza kastedildiğini gördük. Hem bize, hem hemcinslerimize ziyan getirdiklerini gördük. Biz artık aynı hatayı tekrar etmek istemiyoruz ve edemeyiz; biz etmek istesek de, bu millet bize müsaade etmez." ${ }^{37}$ diyerek Patrikliğin çıkarılması kararını savunmuştur.

Türkiye Büyük Millet Meclisi'nde yapılan açık ve gizli görüşmelerde Patrikhâne konusu tartışmalara sebep olmuştur. 25 Aralık 1922 tarihli kapalı oturumda Burdur mebusu İsmail Suphi Bey bu konuda bir takrir vererek özellikle İstanbul'daki Rum ve Ermeniler ile Patrikhânenin mübadeleye tâbi tutulmasının gereğini vurgulamış, Patrikhâneyi hala fesatlıklar yapmakla suçlamıştır. 1 Ocak 1922 tarihinde yapılan kapalı oturumda da Trabzon mebusu ve konferansa giden üyelerden olan Hasan Saka Bey mecliste "Patriğin kovulmasında çok müşkilat çekilecektir...bütün ekalliyetlerin söylendiği bir strada ve bütün memleketlerin verdiği hukukları verdikten sonra bunların kesin surette ortadan kalkması kesin olarak kabul edilmiştir. Binaenaleyh Patrik İstanbul'da kalmaya muvaffak olabilirse, artık eski teşkilat vesaire ile değil, alelade bir Rum papazı ve ruhani bir teşkilat sıfatıyla kalacaktır." açıklamasını yapmıştır. ${ }^{38}$

Atatürk, Patrikhâne konusunda; fesat ve hıyanet ocağ Türkiye'deki Hıristiyanların huzurunu kaçıran ve felaketlere sebep olan Patrikhânenin topraklarımızda bırakılamayacağını, Patrikhâne'nin Türkiye'de kalması için bir sebebin olmadığını ve Patrikhâne'nin yerinin Yunanistan olduğunu belirterek, Yeni Türkiye'nin şeref ve haysiyet, kudret ve kuvvetinin bilincinde hukukunu muhafaza için mevcudiyetini tehlikeye atmaya hazır olduğunu ifade ederek bu konudaki kararlılığını göstermiştir. ${ }^{39}$ Patriğin sadece dini statüsünün kalması karşılığında Türkiye'de kalması basında manşetlere taşınmıştır. Tanin gazetesinin manşeti "Patrikhane kallyor fakat sadece ruhaniyeti kallyor" olmuştur. ${ }^{40}$ Patrikhane ile tartışmalar sürerken bir diğer manşette de "Rumlar için yapacak bir şey kallyor oda Patrikhaneyi İstanbul'dan istedikleri yere nakil etmekten ibarettir." şeklinde olmuştur. ${ }^{41}$

${ }^{37}$ M.Süreyya Şahin, Fener Patrikhânesi ve Türkiye, İstanbul 1996, Ötüken yayın, s.266, 302-304.

${ }^{38}$ TBMMGZC, C.III, Ankara 1985, s.155,173.

${ }^{39}$ Hâkimiyet-i Milliye, 20 Ocak 1923.

${ }^{40}$ Tanin 15 Kasım 1923.

${ }^{41}$ Akşam, 1 Şubat 1925. 


\section{PATRIK KONSTANTIN ARABOĞLU'NUN MÜBADELE MESELESI}

Lozan'da yapılan görüşmeler sonucunda Patrikhâne sorunu çözüme kavuşturulmuştur. Osmanlı Devleti'nde yapılan uygulamada Patrik adayı olan kişinin onayı ileri gelen ayanların da katıldığı bir huzura kabul ile Padişah'a arz edildikten sonra belirlenmekteydi. Şikayetlerini direk Osmanlı Hükûmeti'nin adlî makamlarına yapan Patrik'in Anadolu'daki Osmanlı vatandaşı olan Metropolit'lerden seçilmesi gereği kabul edilmiş, devletin onayı olmadan ister Patrik ister Metropolit olsun yabanc1 bir ülkede yaşayanlar kabul edilmemiş ve Patrikhânenin meclisine seçilecek azanın Türkçe'yi iyi bilmesi şart olarak istenmişti. ${ }^{42}$ Ancak bu tür şartlarının eksik olmasına rağmen Patrik seçilen ve Türkiye aleyhinde faaliyetlerde bulunan Patrik Meletyos, Venizelos'un da baskıları sonucunda istifa ederek, 10 Temmuz 1923 tarihinde Yunanistan'a gitmiştir. ${ }^{43}$ IV. Meletyos'un istifasıly birlikte Patriklik makamı boş kalmış, Sinod Meclisi de valiliğe başvurarak yeni bir seçimin gereğini resmî makamlara bildirilerek seçim için izin istemiştir. Lozan'da alınan kararlardan sonra Türkiye Cumhuriyeti Patrik seçimlerinde yeni bazı düzenlemelere gitmiş, bu değişikliklere göre, Patrik'in Türk vatandaşı ve ruhanî çevresinin de Türkiye'de olması şartı getirilmiştir.

Türkiye, Patrik'in sadece azınlıkların reisi ve görevlerinin din işleriyle sınırlı olduğunu kabul ettiğinden ruhanî olmayanların Patrik olmasını kabul etmemiştir. Ancak Patrik seçimlerine hiçbir müdahalede bulunmayan Türkiye, şartlara uymadığı için 16 Kasım 1924 tarihinde Patrik Grigorios'un yerine Terkos Metropoliti Konstantinos'un Patrik seçilmesine itiraz etmiştir. Bursa doğumlu olan ve Heybeliada'da eğitim gören ve başpapaz olan Konstantin Araboğlu, İstanbul doğumlu olmaması ve 1918 y1lından sonra buraya gelmesinden dolayı mübadelesi gündeme gelerek konu uzun süre tartışılmıştır. ${ }^{44}$

Konstantin Araboğlu Patrik olmasına rağmen siyasî faaliyetlerine devam ederek Romanya ve Çekoslavakya Hükûmetleri'ne ve daha sonra Amerika'ya müracaat ile himaye isteğinde bulunmuştur. ${ }^{45}$ Konstantin Araboğlu'nun Patrik seçilmesi üzerine konu Türkiye tarafından mübadele alt komisyonuna götürülmüş, burada yapılan görüşmelerden sonra karma komisyon kendilerine gelen mesele hakkında 28 Ocak 1925 tarihinde bir açıklama yaparak; "Küçük Asya'da doğmuş, 30 Ekim 1918 den sonra İstanbul'a giderek, nüfus değiş tokuş amacı ile bütün gereken koşulları kendisi yerine getirmis olan Monsenyör Konstantinos Araboğlu'nun değiş tokuşu ile ilgili olarak altıncı yardımcı komitenin 2360 numaralı 17 Aralık

\footnotetext{
${ }^{42}$ Tanin, 31 Aralik 1922.

${ }^{43}$ Hâkimiyet-i Milliye, 11 Temmuz 1923.

${ }^{44}$ İkdam 18 Aralık 1924.

${ }^{45}$ Cumhuriyet, 16 Ocak 1925
} 
1924 tarihli raporunda bulunan gerekçeleri karma komisyon görmüş̧ bulunuyorsa da, başpiskopos olması dolayısıyla konu komisyonun yetkisi dışındadır". şeklinde bir karar bildirmiştir. ${ }^{46}$ Yunanistan'ın konuyu Lahey Adalet Divanı'na götürmesi üzerine, Türkiye; Araboğlu'nun mübadelesi konusunda ısrarlı olmuş iki gün içinde sınır dışı edilmesine karar vermiştir. Karma mübadele komisyonu başkanı General Dölara da görev devir teslim döneminde Konstantin Araboğlu'nun mübadelesi meselesinin Türkiye'nin iç meselesi olduğunu bu sebeple hiçbir vaatte bulunamayacaklarını ifade etmiştir. $^{47}$

Karma Mübadele Komisyonundaki Türk delegesi Hamdi beye telgraf gönderen Türk Hükûmeti, Türkiye'nin bu konudaki görüşlerini; “Araboğlu Konstantin' in mübadelesi başpapaz olduğu için ertelenmişse de mübadelesi kesin ve mecbûridir. Bu konu Türkiye'nin iç meselesidir, Yunanistan Lahey'e gitmekle iç işlerimize karışmaktadır. Rusya'nın daha önce yaptığı gibi bahâne aramaktadır. Lozan antlaşmasının hiçbir maddesi ihlâl edilmemektedir. Eğer komisyon iki gün içinde Araboğlu'nun mübadeleye tâbi olduğuna dair bir karar almazsa, Tâli Komisyonun evvelce almış olduğu karar gereğince ertelenmiş olan mübadele kararı uygulanacaktır" şeklinde bildirmiştir. Karma Mübadele Komisyonu da Araboğlu'nun mübadil olduğu kararını almıştır. ${ }^{48}$ İstanbul Tâli Komisyonu ile Karma Mübadele Komisyonu arasında yapılan resmî yazışmalar sonucunda konunun hukukî yönü çözülmüştür

Patriğin sınır dışı edilmesi kararı üzerine Eksanderis Karma Komisyon'a bir protesto notası vermiş ve Yunan Baş Murahhaslığı'ndan istifa etmiştir. Eksanderis, Karma Komisyon başkanı general Dölara'ya verdiği notada “ Başpapazın mübadele pasaportu olmadan hudut dışına çıkarılmasının gayrı kanuni" olduğunu iddia etmiş ve " cemiyet-i akvâmın yeni devre-i içtimasından önce Rum ekalliyeti aleyhinde hiçbir muamelede bulunulmayacă̆ına dair" Brüksel'de verilmiş olan teminata muhalif olduğunu söylemiştir. "Elefterya" gazetesinin bu konudaki sorusuna Karma Mübadele Komisyonu reisi General Dölara, "Patrik meselesinde Komisyonun haklarına tecavüz yoktur. Gerçekten de Patrik olmadan önce Tâli Komisyona evrâkları verilmiştir mübadeleye tâbidir. Mübadele mukavelenâmesinde bu konuda hiçbir kayıt yoktur" 49 diyerek komisyonun kararını savunmuştur. Akşam gazetesi "Baş Papaz gittikten sonra, Rumlar için yapacak bir şey kalıyor, o da Patrikhâneyi İstanbul dışında istedikleri bir yere nakletmekten ibarettir" manşetini atmıştır. Yine gazeteye göre; Polis müdüriyeti, mübadil oldukları için sevkleri icap eden 3 Metropolit ve 32 papazın memleketlerine gönderilmesi için muamelelerini tamamlamıştır.

\footnotetext{
${ }^{46}$ Cumhuriyet, 29 Ocak 1925; İkdam, 29 Ocak 1925

${ }^{47}$ Akşam, 9 Şubat 1925

${ }^{48}$ Ramazan Tosun, "Patrik VI. Konstantin Araboğlu'nun Mübadelesi", Askeri Tarih
} Bülteni, Y1l:24, S:46, Şubat 1999, s.56-57.

${ }^{49}$ Akşam, 1 Şubat 1925. 
Baş papazın gidişiyle bunlar da gönderilecektir. Yunan murahhas Eksanderis, Araboğlu'nun hudut dışına çıkarılması ile ilgili olarak General Dölara'ya verdiği notada iki sebep dikkat çekmektedir; birincisi, Karma Komisyon dışında mübadillere pasaportun verilemeyeceğidir. Buna göre Türk Hükûmeti baş papaza pasaport vererek mübadele sözleşmesinin 16 . maddesine aykırı davranmıştır. ikincisi Türkiye'nin Milletler Cemiyeti'nin Brüksel ve Roma'daki toplantılarında azınlıkların hakları üzerine verdiği taahhüde uymamasıdır. ${ }^{50}$

Başpapaz Konstantin Araboğlu'nun sınır dışına çıkarılması için Polis müdüriyeti birinci şube müdürü İsmail Hakkı Bey görevlendirilmiş, İsmail Hakkı Bey refakatinde dördüncü şube müdür yardımcısı Osman ile Fener merkez memuru Saffet Beyle birlikte Patrikhâneye hareket etmiştir. Görevlilere karşı fazla bir direnme olmamıştır. ${ }^{51}$ Inzibatların güvenliği altında Sirkeci İstasyonu'na getirilerek yataklı vagon bileti alınmış, uşağı Andon ile beraber 30 Ocak 1925 tarihinde Yunanistan'a sevk edilmiştir. ${ }^{52}$ Patriğin sınırdışı edilmesi üzerine Yunan baş murahhası istifa etmiş, ${ }^{53}$ Konstantin'in Yunanistan'a sevki üzerine Yunan Hükûmeti konunun Lahey Adalet Divanı'na götürülmesi gerektiğini aksi hâlde Ankara'da bulunan maslahatgüzar'ın geri çekileceğini ifade etmiştir. ${ }^{54} \mathrm{Bu}$ mübadelenin yapılmasını Avrupa devletleri nezdinde protesto ederek Türkiye'nin üzerinde baskı kurulması istenmiştir. ${ }^{55}$ Yunanistan'ın bu başvurusu TBMM'de gündeme gelmiş, yapılan görüşmelerde Yunanistan'ın amacının Patrikhânenin güçlü kalması için dünya Ortodokslarının desteğini devam ettirmek olduğu vurgulanmıştır. ${ }^{56}$ Konuyu uluslararası bir mesele hâline getirmeye çalışan Yunanistan Milletler Cemiyeti'ne de bu konuya dahil olmaları için başvurmuştur. ${ }^{57}$

Cumhuriyet gazetesi başyazarı Yunus Nadi, Araboğlu Konstantin'in mübadelesi meselesinde Türkiye'nin hareket tarzının Lozan Antlaşması kararlarına aykırı ve Araboğlu Konstantin'in mübadele sözleşmesine uygun olmadığını söylemiştir. Yunus Nadi, Tali komisyonun Araboğlu Konstantin'in mübadeleye tâbi olduğuna dair bir karar vermişse de tartışmalı bir konu olmasından dolayı uygulanmasına müsaade etmediği ve pasaport vermediğini ama Türkiye Hükûmeti'nin buna rağmen Patriği zorla ihraç ettiğini belirterek, Türk Hükûmeti'nin, Araboğlu'nun yerine seçilecek Patriğe müdahale etmemesi gerektiği görüşünü savunmuştur. ${ }^{58}$ Araboğlu

\footnotetext{
${ }^{50}$ Akşam, 2 Şubat 1925.

${ }^{51}$ Akșam, 31 Ocak 1925.

${ }^{52}$ Cumhuriyet, 31 Ocak 1925.

${ }^{53}$ Akşam, 1 Şubat 1925.

${ }^{54}$ Cumhuriyet, 2 Şubat 1925.

${ }^{55}$ İkdam, 8 Şubat 1925.

${ }^{56}$ TBMMGZC, D:II, İ:II,C:4, s. 463-482.

${ }^{57}$ İkdam, 11 Şubat 1925.

${ }^{58}$ Cumhuriyet, 22 Şubat 1925.
} 
Konstantin'in sınırdışı edilmesinden sonra yeni Patrik seçimi gündeme gelmiştir. Yeni bir patrik seçimi için eski patriğin istifası gerekmiş, ancak Konstantin, Yunanistan'ın desteğiyle istifa etmemekte direnmiş, ${ }^{59}$ meydana gelen krizde Patrikhânenin de sınır dışına çıkarılması ihtimalinin konuşulmaya başlaması üzerine yeni bir başpapaz seçilmesi için istifa etmiştir ${ }^{60}$ Konstantin'in istifasından sonra yapılan seçimde oybirliğiyle Vasilios Başpapaz seçilmiştir. Bundan sonra iki ülke arasında ilişkiler düzelmiş, diplomatik anlamda kesilen ilişkiler, Argyropoulos'un ilk Yunan sefiri olarak atanmasıyla tekrar başlamıştır. Sefirin iyi niyetler içeren konuşmasından sonra ilk Türk elçisi Cevat Bey de aynı yıl içinde göreve başlamıştır. $^{61}$

\section{SONUÇ}

Lozan görüşmeleri sırasında Patrikhane konusu nüfus mübadelesinin tartışıldığı oturumlarda gündeme gelmiş ve tartışmalı bir süreçten sonra çözüme kavuşturulmuştur. Lozan Konferansı süresince Türkiye, Patrikhanenin bütün dünyadaki Ortodoksların lideri sıfatıyla Türkiye'de kalması için başta İngiltere olmak üzere Fransa ve Yunanistan'ın baskısı altında kalmıştır. Türkiye'nin 1 srarlı tutumu karşısında panikleyen Patrikhane şartları kabul etmek zorunda kalmıştır. Sonuçta her ne kadar Türk tarafının "Patrikhanenin sınırdışı edilmesi" görüşü kabul olmamış ise de, Yunan tarafı ile birlikte diğer üyelerin de desteklediği Patrikhanenin sadece ruhaniyetinin kalması şartıyla İstanbul'da kalması görüşü kabul edilmiştir. Patrikhanenin sadece Türkiye Ortodokslarının ruhani temsilcisi olması ve evrensel olmaması şartıyla kabul edilen bu görüş daha sonra tartışmalara konu olmuştur. Bu konulardan en önemlileri, Ekümenlik ve Heybeliada Ruhban Okulu'nun bağımsız olarak açılması konularıdır. Fener Rum Patrikhanesi Laik Türk hukukunca sadece Türkiye'de bulunan Ortodoksların ruhani lideri konumundadır. Patrikhane ise ekümenik kavramını, "ümmet" anlamına dayandırarak bütün dünya Ortodokslarının liderliği olarak algılamaktadır. Halifelik gibi dini statüleri kaldıran Türkiye Cumhuriyeti'nin bu konudaki ısrarlı tutumu sonucunda taraflar kısıtlı ruhani liderliği kabul ile anlaşmaya varmışlardır.

Bugün çeşitli devletler tarafından baskı unsuru olarak dayatılan Patrikhanenin algıladığı "ekümenlik" Türk hukuku açısından halen de geçerli değildir. Ancak Patrikhane kendisini bugüne kadar bu vasıfla ifade etmiştir. Heybeliada Ruhban Okulu'nun durumu bu kavganın bir yüzüdür. Lise artı bir yıl eğitim veren okul statüsünde olan Heybeliada Ruhban okulu Demokrat Parti iktidarında Başbakan Adnan Menderes tarafından Yüksek Okul kapsamına alınmıştır. 1971 yılında anayasa değişikliği ile bu tür kurumların tamamının Milli Eğitim Bakanlığı'na bağlanmasıyla özerk

\footnotetext{
${ }^{59}$ Cumhuriyet, 28 Şubat 1925.

${ }^{\star 0}$ Cumhuriyet, 19 Nisan, 20 Mayıs 1925.

${ }^{61}$ Cumhuriyet, 14-21 Temmuz 1925.
} 
statüsünü kaybeden okul, eğitimine ara vermiştir. Patrikhane, Türk vatandaşı olmayanların öğrenci olamayacağı gibi bir şartı olan okula bu gün dişarıdan öğrenci alma girişimlerinde bulunmakta bu şekilde dolaylı yoldan ekümenikliği hayata geçirmek istemekte, bu amaçla ruhban okulunu bağımsız ve fakülte denginde açmak için çalışmaktadır. Bu gün de Mustafa Kemal Atatürk'ün çizdiği laik hukuk devletinde kendi hukuku olan ve devletin tam bağımsızlık ilkesini yaralayan bir kurum haline getirilmek istenen Patrikhanenin yetkileri, konumu ve ruhaniyetinin yanında siyasi bir gücünün olması meselesi tartı̧̧ma konusu yapılmaktadır. Avrupa Birliği uyum yasaları çerçevesine alınarak yeni düzenlemelerle, Lozan'da başarılamayan Patrikhanenin "Ekümenlik" olması konusu Heybeliada Ruhban Okulu vasıtasıyla kabul ettirilmeye çalışılmaktadır. Lozan'da olduğu üzere değişmeyen taraflar bugün bu konuyu hukuki ve siyasi kriterler çerçevesinde Türkiye'den istemektedir.

\section{KAYNAKLAR}

Arşiv, Meclis Zabtlart ve Gazeteler

Akşam

Cumhuriyet

Hâkimiyet-i Milliye

İkdam

Tanin

TBMM Gizli Zabıt Cerideleri, Başbakanlık Cumhuriyet Arşivi

\section{Kitaplar}

Adnan Sofuoğlu, Fener Patrikhânesi ve Siyasî Faaliyetleri, İstanbul 1996, TTK yayını,

G. Ostrogorsky, Bizans Devleti Tarihi, çev: F. Işıltan, Ankara 1981, TTK yayını,

Cevdet Paşa, Tarihi Cevdet, XI, İstanbul 1983, Akçă̆ Yay.

Mustafa Ekincikli, Türk Ortodoksları, Ankara 1998.

Bülent Atalay, Fener Rum Patrikhanesinin Siyasi Faaliyetleri (1908-1923), İstanbul 2001, Tarih ve Tabiat Vakfı yayını:4.

Pontus Meselesi, Yılmaz Kurt (yayına hazırlayan ), Ankara 1995.

Mustafa Kemal Atatürk, Nutuk, C.I, İstanbul 1950.

Selahattin Salıșı, Tarih Boyunca Türk-Yunan İlişkileri ve Etnik-i Eterya, İstanbul, 1968 ,s.44.

İsmet İnönü, İsmet İnönü’nün Hatıraları (1923-1938), C.II, İstanbul 1998. 
Seha L. Meray, Lozan Barış Konferansı Tutanakları-Belgeler, İstanbul 1993, Yapı Kredi Yayınları (3. baskı)

Bilal N. Şimşir, Lozan Telgrafları 1922-1923, C:I, TTK yayını, Ankara 1990.

M.Süreyya Şahin, Fener Patrikhânesi ve Türkiye, İstanbul 1996.

\section{Makaleler}

Yavuz Ercan, "Türk-Yunan İlişkilerinde Rum Patrikhânesinin Rolü”, Üçüncü Askeri Tarih Semineri Bildirileri, Tarih Boyunca Türk Yunan İlişkileri, Ankara 1986.

Sabahattin Özel, "Mili Mücadele'de Yunanistan ve Fener Rum Patrikhânesinin İstanbul'daki Faaliyetleri ve Atatürk'ün Patrikhâne konusundaki Görüşleri”, Askeri Tarih Bülteni, S:40, Ankara 1996.

İzzet Öztoprak, “Trabzon Muhafaza-i Hukuk Cemiyeti”, Birinci Tarih Boyunca Karadeniz Kongresi Bildirileri (13-17 Ekim 1986), Samsun 1988.

Ramazan Tosun, "Patrik VI. Konstantin Araboğlu'nun Mübadelesi”, Askeri Tarih Bülteni, Yıl:24, S:46, Şubat 1999. 


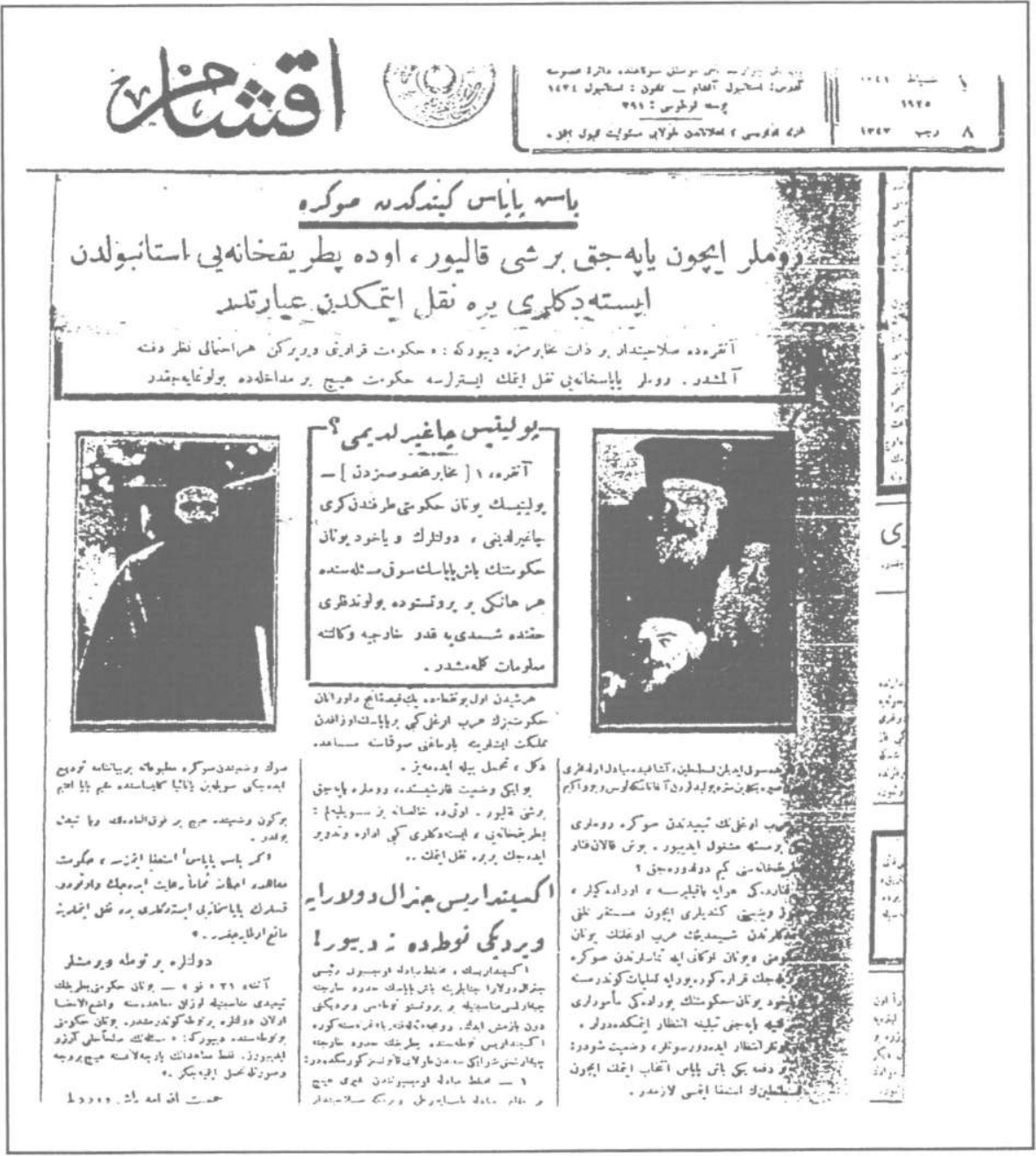

EK-I 


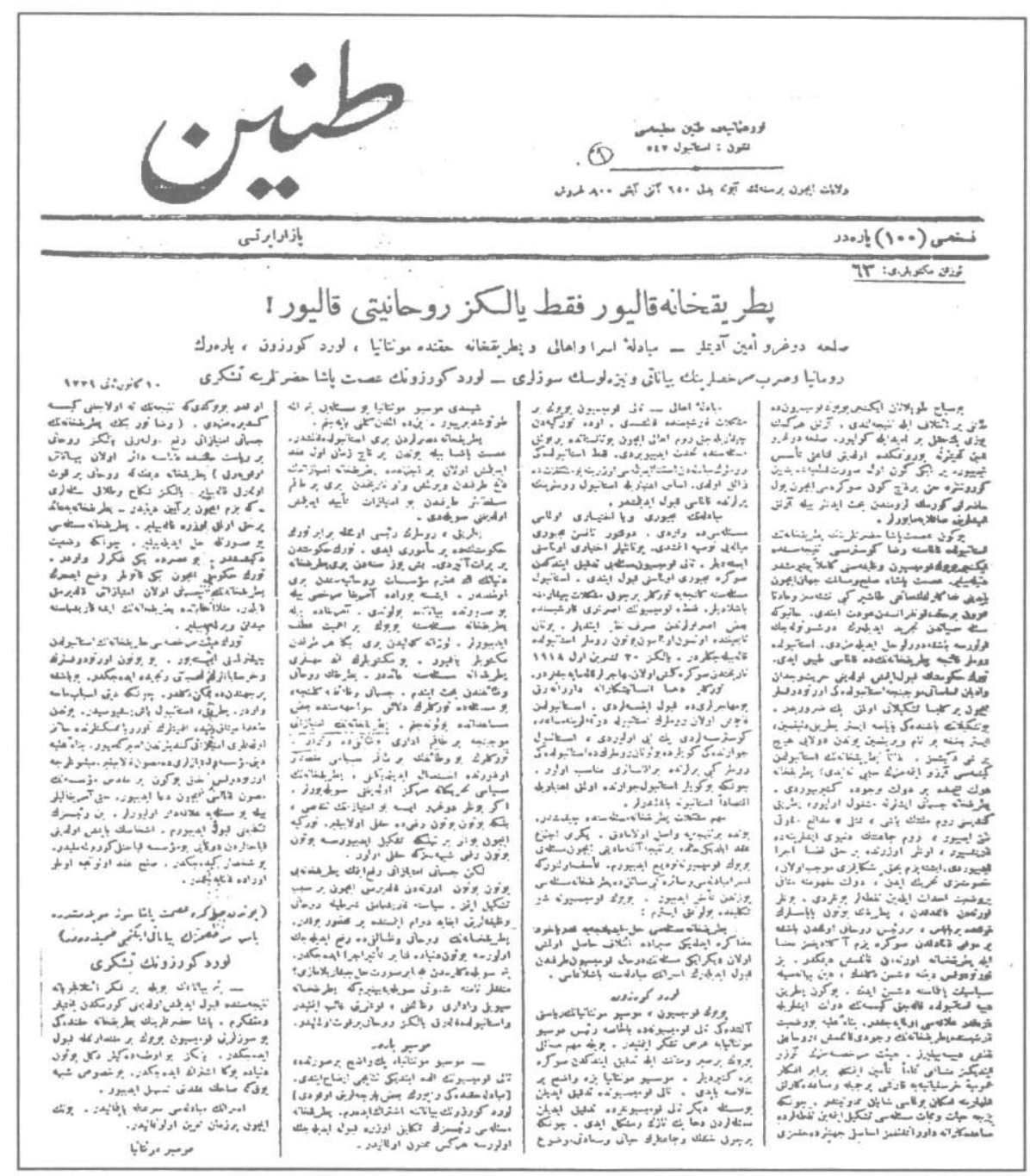

EK-II 


$$
7
$$

